\title{
NILAI-NILAI FILOSOFIS BATIK BANJAR JAWA BARAT
}

\author{
Indah Mulyani ${ }^{1}$, Yeni Wijayanti' ${ }^{2}$, Egi Nurholis ${ }^{3}$ \\ 1,2,3 Program Studi Pendidikan Sejarah, Universitas Galuh, Jl. R.E. Martadinata No, 150, Ciamis, Indonesia \\ email: indahmulyani2908@gmail.com², yeniunigal@gmail.com², eginurholis@gmail.com³
}

\begin{abstract}
Batik is the result of ancestral heritage, where every creation has a meaning behind the motif. This study aims to determine the development and philosophical values contained in Banjar City Batik. The research method uses historical methods, namely heuristics, verification or source criticism (external criticism and internal criticism), interpretation, and historiography. The results showed that batik typical of Banjar City is the result of a craft created after a batik design competition held by the National Arts and Crafts Council of Banjar City in 2010. The winner was the Tarum Motif by Heri Susanto, which described the environmental conditions of Banjar City and became a Banjar City batik from 2011 until now. Banjar batik becomes official clothing worn by all Banjar City government officials every Thursday. The Amendment to Mayor Regulation Number 23 of 2018 is regulated about it. Then In 2020, the Directorate General of Haki (Intellectual Property Rights) filed a patent for batik motifs typical of the City of Banjar. The philosophical values contained in Banjar City batik include aesthetic values, economic values, socio-cultural values , and educational values.
\end{abstract}

Keywords: Value, Philosophy, Batik, Banjar City.

\section{ABSTRAK}

Batik merupakan hasil warisan nenek moyang, dimana setiap kreasi memiliki makna dibalik motifnya. Penelitian ini bertujuan untuk mengetahui perkembangan dan nilai filosofi yang terkandung dalam Batik Kota Banjar. Metode penelitian menggunakan metode historis, yaitu heuristik, verifikasi atau kritik sumber (kritik eksternal dan kritik internal), interpretasi, dan historiografi. Hasil penelitian menunjukkan bahwa batik khas Kota Banjar merupakan hasil kerajinan yang dibuat setelah lomba desain batik yang diadakan oleh Dewan Seni dan Kerajinan Nasional Kota Banjar tahun 2010. Pemenangnya adalah Motif Tarum karya Heri Susanto yang menggambarkan kondisi lingkungan. Kota Banjar dan menjadi batik Kota Banjar dari tahun 2011 sampai sekarang. Batik Banjar menjadi pakaian resmi yang dikenakan oleh seluruh pejabat pemerintah Kota Banjar setiap hari Kamis. Hal tersebut diatur dalam Perubahan Peraturan Walikota Nomor 23 Tahun 2018. Kemudian Tahun 2020, Direktorat Jenderal Haki (Hak Kekayaan Intelektual) mengajukan paten untuk motif batik khas Kota Banjar. Nilai filosofi yang terkandung dalam batik Kota Banjar meliputi nilai estetika, nilai ekonomi, nilai sosial budaya, dan nilai pendidikan.

Kata Kunci: Nilai, Filosofi, Batik, Kota Banjar.

Cara sitasi: Mulyani, I., Wijayanti, Y., \& Nurholis, E. (2021). Nilai-Nilai Filosofis Batik Banjar Jawa Barat. J-KIP (Jurnal Keguruan dan IImu Pendidikan), 2 (3), 21-32. 


\section{PENDAHULUAN}

Batik merupakan warisan budaya nenek moyang secara turun-temurun. Batik Indonesia tumbuh dan berkembang menyertai dinamika masyarakat. Di antara beragam kebudayaan Indonesia, batik merupakan karya seni yang sangat unik dan bernilai tinggi, tidak hanya memiliki nilai estetika yang terkandung didalamya namun nilai-nilai filosofis yang tertuang dalam batik (Supriono, 2016). Di setiap masa dan daerah batik memiliki ragam hias dan teknik yang beranekaragam sesuai kebudayaan yang berkembang di masyarakat.

Perkembangan batik diperkirakan sejak abad XII Masehi, sejarah perkembangan batik erat kaitannya dengan Kerajaan Majapahit dan semakin pesat pada masa Kerajaan Islam Indonesia. Batik pada masa Kerajaan Majapahit diinterpretasikan dari berbagai kain yang dikenakan pada sejumlah arca batu salah satunya arca Kertajasa yang menggambarkan Raden Wijaya sebagai pendiri Majapahit dalam perwujudannya sebagai Harihara, memakai Batik Motif Kawung. Dan atas dasar itulah motif kawung dianggap sebagai batiknya para bangsawan Jawa. Perkembangan batik pada Kerajaan Islam di Indonesia yakni tatkala terpecahnya Kerajaan Mataram Islam menjadi Kesultanan Yogyakarta dan Kasunanan Kartasura akibat perjanjian Giyanti, yang berdampak pula pada perkembangan batik. Seluruh busana kebesaran Kerajaan Mataram Islam dibawa ke Keraton Yogyakarta, sementara pada Kasunana Surakarta, Paku Buwana III memerintahkan untuk membuat sendiri motif batik Gagrak Surakarta (Supriono, 2016).

Pada awalnya seni dan keterampilan membatik hanya tumbuh di lingkungan keraton. Hasilnya untuk pakaian raja dan keluarga, serta para pengikutnya (Musman \& Arini, 2011). Dalam kehidupan masyarakan jawa pada zaman dahulu seni batik bukan hanya untuk melatih keterampilan melukis namun digunakan sebagai Pendidikan etika dan estetika bagi wanita zaman dulu (Kusriyanto, 2013), jadi tidak sembarang orang dapat memiliki batik. Namun seiring dengan perkembangan zaman batik tidak hanya dimiliki oleh kalangan bangsawan tetapi dapat di miliki oleh semua kalangan, perkembangan batik selanjutnya sebagai salah satu mata pencaharian dalam perekonomian khususnya bagi kalangan wanita.

Seiring dengan perkembangan motif dan kegunaan batik, perkembangan ini pula terjadi pada teknik pembuatan batik. Ditinjau dari segi teknik pembuatannya dikenal secara umum teknik dalam pembuatan batik dibedakan menjadi batik tulis, batik jumputan, batik cap, batik printing, dan batik sablon malam. Pada awalnya teknik pembuatan batik dilakukan secara tradisional yaitu menggunakan tenaga manusia melalui penggoresan malam atau lilin pada kain dengan bantuan canting sesuai dengan motif yang diinginkan, teknik membatik ini dinamakan dengan batik tulis. Seiring dengan perkembangan teknologi pembuatan batik dikalukan dengan menggunakan alat yang memudahkan dan membuat produksi batik dapat dilakukan dengan mudah dan cepat yakni dengan teknik cap, sablon, dan printing (Supriono, 2016).

Batik sebagai warisan budaya Indonesia telah diakui oleh UNESCO (United Nations of Educational, Scientific, and Cultural Organization) ditetapkan sebagai warisan kemanusiaan untuk budaya lisan dan non-bendawi (Masterpieces of The Oral and Intangible Heritage of Humanity). Batik Indonesia merupakan suatu keseluruhan teknik, teknologi, serta pengembangan motif dan budaya (Musman \& Arini, 2011). Selain itu setiap tanggal 2 Oktober selalu diperingati sebagai hari batik nasional.

Batik yang kita kenal saat ini sebenarnya merupakan perwujudan dari karya seni atau kebudayaan yang bersifat indrawi, filosofis, dan spiritual. Selain memiliki nilai estetika dalam motif batik yang tertuang dari segi warna dan ornament yang membentuk suatu seni batik juga memiliki nilai-nilai fiosofi. Batik bukan hanya mengekspresikan keindahan secara visual tetapi juga memancarkan nilai-nilai filosofi dan pengalaman spiritual yang dalam (Supriono, 2016). Setiap motif batik dibeberapa daerah di Indonesia pada dasarnya mempunyai ciri khasnya masing-masing karena di setiap daerah mempunyai tradisi dan kebiasaan yang berbeda-beda. Misalnya, perbedaan antara batik Jawa Tengah dan batik Jawa Barat keduanya mempunyai ciri khasnya tersendiri (Herdiana, Soedarmo \& Kusmayadi, 2020). 
Nilai estetika diartikan sebagai nilai keindahan, pengertian estetika menurut The Liang Gie pada pokoknya, estetika adalah filsafat tentang hal yang indah, ilmu tentang keindahan dan citarasa dan menurut Martin Suryajaya secara etimologis, istilah estetika berasal dari kata sifat dalam Bahasa Yunani, aisthetikos yang artinya persepsi indrawi (Susanti, 2018). Di mana dalam mengapresiasi suatu keindahan seni dapat dirasakan manusia melalui indrawi atau panca indra ketika berinteraksi terhadap suatu karya seni. Namun, keindahan tidak hanya terbatas pada suatu benda yang terserap melalui penglihatan berdasarkan bentuk dan warna saja, melainkan keindahan sebagai estetik murni yang berusaha mengungkapkan pengalaman estetik dari seseorang dalam kaitannya dengan segala sesuatu yang diserapnya (Hidayatuloh, 2019). Karya seni tidak hanya berbicara mengenai keindahan namun dalam penciptaan karya seni tidak terlepas dari menggambarkan suatu peristiwa atau harapan yang dituangkan melalui sebuah karya seni diantaranya adalah batik.

Daerah yang telah dikenal sebagai penghasil batik di Jawa Barat adalah Cirebon, Tasikmalaya, Ciamis, Indramayu, Garut, Kuningan, Sumedang dan Bandung. Kota Banjar yang merupakan wilayah baru akibat pemekaran dari Kabupaten Ciamis berusaha membuat identitas daerahnya sendiri. Sejarah Kota Banjar tidak terlepas dari sejarah berdirinya Pemerintahan Kabupaten Ciamis di masa lalu (https://banjarkota.go.id/). Kota Banjar tercatat sebagai kota pemekaran dari Kabupaten Ciamis sejak 2002 dengan dikeluarkannya Undang-Undang No. 27 Tahun 2002 tentang pembentukan Kota Banjar yang secara resmi memiliki daerah administatif sendiri, tentunya kebudayaan masyarakat Kota Banjar tidak terlepas dari Kebudayaan dari Kabupaten Ciamis, namun yang menjadi ciri khas yang sangat nampak dari Kota Banjar adalah akulturasi budaya Jawa dan Sunda, karena ditinjau dari segi geografis Kota Banjar terletak di perbatasan Jawa Barat dan Jawa Tengah, hal ini nampak dalam segi penggunaan bahasa di dalam masyarakat dan dapat dilihat dari berbagai aspek lainnya.

Kota Banjar adalah salah satu kota di Provinsi Jawa Barat yang berbatasan dengan Provinsi Jawa Tengah, yakni Kabupaten Cilacap. Banjar merupakan menjadi pintu gerbang utama jalur lintas Selatan Jawa Barat. Meskipun belum lama tercatat sebagai daerah yang memiliki administratif sendiri Kota Banjar telah memiliki ciri khas daerahnya salah satunya adalah seni batik dan Batik Kota Banjar masih terbilang baru karena tercipta dari hasil lomba.

Perkembangan terbentuknya Kota Banjar tentunya berusaha mewujudkan daerah yang memiliki ciri khas kebudayaan yang menjadi identitas sendiri di daerah tersebut, tidak hanya dari segi budaya, namun kehidupan ekonomi, pemerintahan dan sebagainya. Salah satu wujud dari perkembangan identitasnya adalah terciptanya seni khas daerah yaitu seni batik yang memiliki motif yang tidak terlepas dari sosial budaya masyarakat Kota Banjar.

Berdasarkan latar belakang mengenai batik sebagai warisan budaya dan salah satu identitas di suatu daerah maka penelitian dilakukan untuk mengkaji makna fiosofis yang terkandung dalam seni batik. Dengan demikian penulis mengambil judul yaitu: "Nilai-Nilai Filosofis Batik Banjar Jawa Barat". Dengan fokus masalah yaitu: Bagaimana perkembangan dan nilai-nilai filosofis yang terkandung dalam Batik Kota Banjar Jawa Barat?.

\section{METODE PENELITIAN}

Metode yang di gunakan adalah metode sejarah yang terdiri dari heuristik, Kritik, interpretasi dan historiografi. Yang merupakan proses menguji dan menganalisa secara kritis rekaman dan peninggalan masa lampau (Gottschlak). Melalui seperangkat prinsip dan aturan sistematis untuk pengumpulan sumber-sumber sejarah, menilainya secara kritis, dan menyajikan suatu sintesis (umumnya dalam bentuk tertulis) hasil yang dicapai (Gilbert J. Garraghan; Herlina, 2020). Adapun Subyek penelitian ini adalah batik khas daerah Kota Banjar Provinsi Jawa Barat yang akan dianalisis berdasarkan nilai-nilai filosofisnya. Adapun lokasi penelitiannya di Kota Banjar Jawa Barat. Objek sasaran penelitian adalah industri-industri pengrajin batik di Kota Banjar yakni, Gendhies Batik berlokasi di belakang bank BTPN, Jl. Pamarican No.102, Hegarsari, Kec. Pataruman, Kota Banjar, 
Jawa Barat 46322 dan Yola Batik berlokasi di JL. Lingkungan Siluman, RT. 25 RW. 12, Purwaharja, Banjar, Kota Banjar.

Tahap awal dalam penelitian yaitu heuristik atau disebut pengumpulan sumber. Teknis pengumpulan data dilakukan melalui; (a) Observasi, pencarian informasi mengenai keberadaan Batik Banjar dan nilai-nilai filosofis Batik Banjar dengan mengunjungi industri pengrajin batik yang ada. Selanjutnya melakukan wawancara, untuk lebih dalam menggali mengenai nilai-nilai filosofisnya dan untuk mendapatkan informasi dari pihak-pihak yang terkait keberadaan Batik Banjar. Dokumentasi, dilakukan untuk mengumpulkan sejumlah dokumen yang diperlukan sebagai bahan data informasi sesuai dengan masalah penelitian, seperti peta, data statistik, jumlah dan nama pegawai, data siswa, data penduduk; grafik, gambar, surat-surat, foto, akte, dan sebagainya. Dan Studi literatur, dilakukan peneliti dengan mengunjungi perpustakaan yang berada di lingkup Universitas Galuh, Perpustakaan Daerah Kabupaten Ciamis, Perpustakaan Daerah Kota Banjar, selain itu juga dilakukan pencarian sumber melalui website dan artikel ilmiah atau e-journal yang dianggap relevan dengan topik yang diteliti.

Langkah selanjutnya yaitu kritik, untuk memverifikasi keabsahan data yang terkumpul, terutama sumber pertama bertujuan agar terjaring fakta yang menjadi pilihannya. Terdapat dua macam verifikasi, yaitu kritik ekstern untuk meneliti otentisitas sumber, atau keaslian sumber dan kritik internal untuk meneliti kredibilitas sumber.

a. Kritik ekstern, difokuskan untuk menganalisis dan pembuktian keaslian sumber berdasarkan unsur yang membentuk data tersebut, dalam melakukan kritik ektern dilakukannya uji terhadap sifat-sifat atau ciri-ciri fisik. Penulis melakukan kritik ektern sumber lisan terhadap nasarumber berdasarkan kriteria yang telah ditetapkan sebagai pertimbangan. Kritik ekstern dilakukan pada narasumber: Neni (47 tahun), Mimin (63 tahun), Heri (47 tahun), Hj. Lalak (57 tahun) yang merupakan pengrajin Batik Kota Banjar dan Yadi (38 Tahun) sebagai Kepala Seksi Sarana Prasarana dan Pemberdayaan Sumber Daya Industri, dengan ini penulis beranggapan bahwa narasumber cukup mengetahui mengenai Batik Kota Banjar baik dilihat dari kondisi fisik, profesi dan ingatan yang cukup baik.

b. Kritik intern, menekankan pada aspek "dalam" yaitu membuktikan kredibilitas data yang diperoleh dengan menganalisis isi yang terdapat pada data tersebut dan melakukan uji validitas terhadap sumber tertulis dan sumber lisan. Pada sumber tertulis penulis melakukan kritik intern terhadap beberapa penelitian yang telah dilakukan mengenai batik, diantaranya adalah: Tyas (2013) Analisis Semiotika Motif Batik Khas Samarinda, Purnamasari (2015) Sejarah Perkembangan, Makna, dan Nilai Filosofis Batik Srikit khas Kabupaten Kebumen Provinsi Jawa Tengah, Herdiana, Soedarmo, \& Kusmayadi (2020) Motif Ragam Hias Dan Nilai-Nilai Filosofis Batik Ciamisan, dan Grenita Indah Susanti (2018) Kajian Estetik Batik Sekar Jagad Motif Mancungan Kebumen. Yuyun Yunita (2016) Makna Filosofis Batik Kendal. Dari beberapa penelitian tersebut menjelaskan mengenai batik namun memiliki subjek penelitian yang berbeda. Dengan demikian penulis mengidentifikasi kembali dari sumber tersebut untuk mengetahui fakta sebenarnya, sehingga terlihat kelayakan isi sebuah sumber sejarah. Sedangkan dari data lisan yang diperoleh untuk mengetahui kredibilitas dari sumber tersebut dilihat dari segi isi yang disampaikan pelaku atau saksi sejarah itu, semua tergantung pada kejujuran pelaku atau saksi sejarah tersebut apakah sumber itu dapat dipercaya atau tidak. Kritik intern yang dilakukan dari sumber lisan yang diperoleh melalui wawancara, penulis memperoleh fakta bahwa adanya persamaan jawaban mengenai penjelasan Batik Banjar.

Interpretasi merupakan langkah penafsiran fakta-fakta atau sering disebut sebagai biang subjektifitas. Interpretasi diperlukan karena pada dasarnya bukti-bukti sejarah sebagai saksi (witness) realitas di masa lampau adalah hanya saksi-saksi bisu belaka. Fakta-fakta atau bukti-bukti dan saksi-saksi sejarah itu tidak bisa berbicara sendiri mengenai apa yang disaksikannya dari realitas masa lampau (Daliman, 2018). Langkah terakhir dalam penelitian sejarah adalah 
Historiografi atau penulisan sejarah sesuai dengan fakta-fakta yang telah terkumpul dan telah melalui analisis terhadap data yang sesuai dengan topik penelitian.

\section{HASIL PENELITIAN DAN PEMBAHASAN Perkembangan Batik Kota Banjar}

Kota Banjar merupakan salah satu Kota di Jawa Barat yang memiliki batik khas daerahnya, meskipun keberadaan batik di Kota Banjar dapat dikatakan belum lama. Perkembangan batik di Kota Banjar tidak bisa dipisahkan dengan perkembangan Kota Banjar menjadi kota yang mandiri setelah memishkan diri dari wilayah Kabupaten Ciamis.

Kemunculan motif batik yang menjadi ciri khas Kota Banjar dapat dikatakan masih tergolong baru yakni tercipta dari hasil lomba desain yang diselenggarakan oleh Dekranasda (Dewan Kerajinan Nasional Daerah) Kota Banjar pada 2010. Lomba desain ini diselenggarakan untuk menciptakan motif batik yang menjadi ciri khas dari Kota Banjar. Juri pada saat lomba desain batik adalah H. Komarudin Kudiya, S. IP., M. Ds., Yayasan Batik Barat beliau juga merupakan Chief Executife Officer (CEO) Batik Komar yang berlokasi di Bandung; Herman Yusuf S. Pd., dari Institut Teknologi Bandung (ITB); dan Deddy S. Yasya dari Aparatur Kota Banjar. Atas hasil keputusan juri, motif batik yang terpilih menjadi juara adalah Motif Tarum yang menggambarkan kondisi lingkungan Kota Banjar karya Heri Susanto (2021), motif batik Tarum dijadikan juara lomba dan dijadikan batik Khas Kota Banjar Patroman karena adanya kesesuaian dengan kriteria penilaian juri pada perlombaan tersebut yaitu adanya originalitas desain, kesesuaian tema, keunikan desain, dan keindahan. Hal inilah yang kemudian menjadi cikal bakal adanya motif Batik Khas Kota Banjar (Kusdiani, 2018).

Awal berdirinya industri kerajinan batik di Kota Banjar yaitu setelah adanya lomba desain motif batik khas Kota Banjar pada November 2010 (Lalak, wawancara 1 Maret 2021). Untuk menjaga eksistensi batik yang menjadi salah satu ciri khas daerah Kota Banjar munculah industriindustri batik yang berusaha untuk tetap melestarikan Batik Kota Banjar dengan memproduksinya secara masal dan agar dapat dikenal ataupun digunakan warga masyarakat Kota Banjar pada khususnya serta pada khalayak umum lainnya. Industri batik di Kota Banjar muncul setelah diresmikan. Terdapat lima industri batik yang berdiri pada awal kemunculannya, namun seiring berjalannya waktu karena banyaknya pesaing perdagangan yang mengedepankan kualitas produk, dan kondisi pandemi yang berdampak pada berkurangnya penjualan, industri batik di Kota Banjar berkurang menjadi dua industri batik yang diketahui keberadaaa dan masih beroperasi hingga kini yaitu Home Industry Gendhies Batik yang dikelola oleh Heri sebagai pemenang lomba desain batik dan Yola Batik yang dikelola oleh $\mathrm{Hj}$. Lalak.

Batik Kota Banjar diresmikan pada 2011, launching pertama Batik Kota Banjar oleh walikota Banjar Patroman yaitu dr. Herman Sutrisno M.M. Disaksikan oleh ketua Yayasan Batik Jawa Barat yaitu Sendy Yusuf. Acara launching ini untuk memperkenalkan kepada masyarakat luas dan khususnya masyarakat Kota Banjar bahwa Batik Tarum Ébég telah diresmikan sebagai motif batik khas Kota Banjar berdasarkan surat keputusan (SK) yang dikeluarkan Walikota Banjar (Kusdiani, 2018, Yadi wawancara 29 Juni 2021).

Setelah diresmikan pada 2011 keberadaan Batik Kota Banjar mulai dilakukan produksi secara masal dan berusaha meluaskan pemasarannya dengan melakukan promosi melalui akun sosial media, penjualan yang dilakukan tidak hanya dalam daerah namun hingga luar daerah Kota Banjar yakni Bandung, Jakarta bahkan sampai ke luar Pulau Jawa (Lalak, wawancara 1 Maret 2021). Inovasi terus dilakukan agar batik terus eksis dan tetap stabil dipasaran dan tetap diminati oleh masyarakat luas. Inovasi yang dilakukan adalah pengembangan motif-motif batik dengan mengkolaborasikan Motif Tarum dan Ébég dengan motif lainnya. Dalam hal ini batik harus dapat memenuhi selera yang diinginkan konsumen. Produksi batik dilakukan baik saat adanya pesanan maupun produksi secara berkala, kain batik yang dihasilkan saat produksi dapat mencapai 600 lembar kain per bulan dengan karyawan berjumlah 7 orang, namun setalah adanya pandemi Covid- 
19 yang telah berlangsung selama kurang lebih 1 tahun dari mulai tahun 2020, produksi batik yang dilakukan hanya mencapai 10 lembar kain saja dalam satu minggu (Mimin, wawancara 18 Februari 2021).

Pada tahun 2018 Batik Kota Banjar secara resmi wajib dikenakan oleh jajaran Pemerintahan Kota Banjar dengan disahkannya peraturan daerah tentang pakaian dinas pemerintahan Kota Banjar yang di atur dalam Perubahan Atas Peraturan Wali Kota Nomor 23 Tahun 2018 Tentang Pakaian Dinas Pegawai Negeri Sipil Di Lingkungan Pemerintah Daerah Pasal 32 ayat 1 Poin C yang berbunyi "PDH Batik Banjar dipergunakan pada Hari Kamis, bagi wanita berkerudung menggunakan kerudung warna biru dongker/hitam, polos/tidak bermotif" (https://peraturan.bpk.go.id). Hal ini dilakukan agar Batik Kota Banjar tetap eksis. Upaya pemerintah lainnya dalam menjaga eksistensi Batik Kota Banjar dilakukannya pembinaan terhadap para pelaku industri batik dengan membatu dalam promosi dan pemasarannya, kemudian di tahun 2020 dilakukannya pengajuan hak paten terhadap motif-motif batik khas Kota Banjar pada Ditjen Haki (Hak Kekayaan Intelektual), namun belum mengeluarkan hasil paten karena masih dalam proses.

\section{Nilai-Nilai Filosofis Batik Kota Banjar}

Pada dasarnya motif batik yang menjadi ciri khas dari Batik Kota Banjar adalah terinspirasi dari kondisi lingkungannya dimana terdapat aliran sungai citanduy yang banyak tumbuh tanaman merambat yaitu pohon tarum, hal ini pula menjadikan Kota Banjar sering disebut dengan nama Banjar Patroman yaitu kata lain untuk menyebutkan kata "Pataruman" oleh masyarakat Kota Banjar. Motif-motif pada Batik Kota Banjar tergolong jenis motif batik modern dengan motif dan penggunaan warna yang sederhana namun masih elegan dan terlihat keindahan dari setiap motif-motifnya.

Selanjutnya adalah penggambaran kondisi budaya yang berada di daerah Kota Banjar juga merupakan inspirasi terciptanya motif batik yakni kesenian Kuda Lumping atau Ébég, meskipun bukan kesenian asli Kota Banjar namun kesenian ini sangat dikenal oleh masyarakat tersebut, hal ini dikarenakan kondisi geografis Kota Banjar yang berbatasan langsung dengan Provinsi Jawa Tengah menjadikan Kota Banjar memiliki budaya yang heterogen.

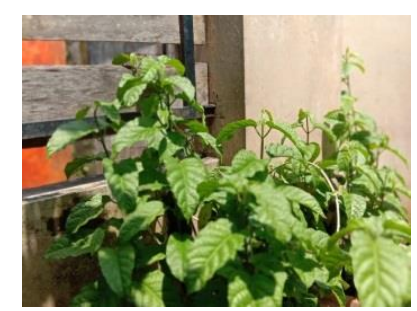

Gambar 1. Pohon Tarum

Sumber: Dokumentasi Pribadi, 2021.

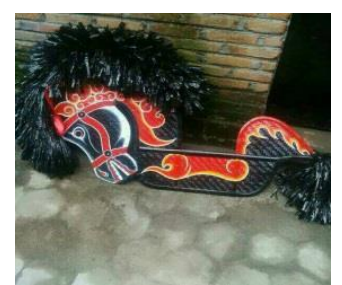

Gambar 2. Kuda Lumping/Ébég

Sumber: https://www.tokopedia.com/liana-sidomulyo/kudalumping-asli-untuk-pentas diakses pada 29 April 2021.

Berikut merupakan motif-motif batik yang menjadi ciri khas Batik Kota Banjar:

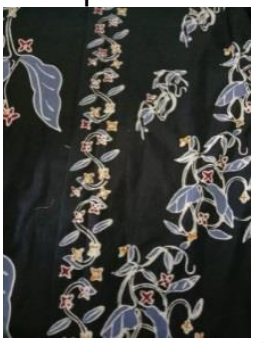

Gambar 3. Motif Tarum Ébég Sumber: Dokumentasi Pribadi, 2021.

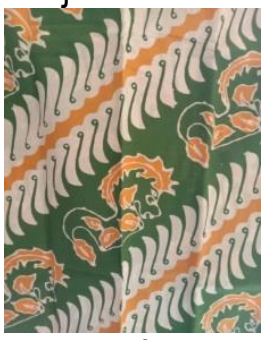

Gambar 4. Motif Réréng Ébég Sumber: Dokumentasi Pribadi, 2021.

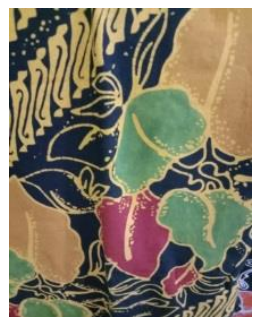

Gambar 5. Motif Réréng Tarum Sumber: Dokumentasi Pribadi, 2021.

Batik Tarum Ébég tergolong dalam batik modern, dimana makna dalam motif dan warnanya tidak adanya pakem-pekem tertentu seperti pada batik klasik. Warna latar atau background dalam batik tersebut yaitu warna biru tua. Warna latar Batik Tarum Ébég sengaja menggunakan warna 
lebih gelap dari warna utama dan warna pelengkap, supaya terkesan lebih kalem (Kusdiani, 2018). Warna biru mengandung makna kepercayaan, setia, damai, kesejukan, percaya diri, keamanan, laut, langit, damai, harmoni, kelembutan, kehebatan, loyalitas, kebijaksanaan, dan kekuatan (Susanti, 2018). Terciptanya motif Tarum Ébég ini terinspirasi oleh kondisi lingkugan Kota Banjar yang terdapat jenis tanaman merambat yaitu Tarum dan Keseniannya Ébég. Yang dituangkan dalam motif batik. Pohon tarum dahulunya banyak dijumpai di sekitar Sungai Citanduy sehingga menjadi ikon Kota Banjar yang sering disebut dengan Banjar Patroman atau Banjar Pataruman yang terinspirasi dari nama Tarum. Sedangkan Ébég pada motif Batik Tarum Ébég digambarkan dengan Pohon Tarum yang membentuk Ébég. Motif Tarum Ébég menggambarkan kondisi masyarakat Kota Banjar yang memiliki kerukunan hidup di dalam kehidupan yang heterogen. Kemudian motif Tarum Ébég ini dikembangkan dengan mengkolaborasikan motif-motif batik yang telah ada yakni Motif Réréng yang menjadi Motif Réréng Tarum dan Motif Réréng Ébég.

Motif Réréng telah ada sejak dulu dan dijadikan sebagai salah satu motif Batik Priangan. Motif yang menggambarkan tebing miring ini dipengaruhi Motif Parang pada Batik Jawa Tengah (Herlinawati, 2012). Motif parang sesungguhnya merupakan deformasi dari beberapa bentuk, yakni bentuk ombak laut yang susul-menyusul mengandung makna bahwa dalam dunia ini tidak ada yang mulus, banyak cobaan hidup yang akan dilalui dan bila dihadapi dengan bijak akan melahirkan ketegaran. Bentuk kedua adalah pusaran ombak yang dilintasi menjadi bentuk intan yang dalam istilah batik disebut mlinjon yang memisahkan satu baris dengan baris berikutnya, bentuk ini bermakna bahwa perjuangan seorang pemimpin ibarat berjuang di dalam pusaran air, bila ia berhasil akan diibaratkan menemukan permata (Kusriyanto, 2013). Selanjutnya motif lain yang merupakan pengembangan dari motif Tarum Ébég adalah motif Ébég.Bilik.

Motif Ébég Bilik merupakan kolaborasi antara Motif Tarum yang membentuk Ébég dengan Motif Bilik. Bilik merupakan kerajinan tangan dengan teknik menganyam, yaitu mengatur bahanbahan dasarnya dalam bentuk tindih menindih, silang menyilang, lipat melipat, dan sebagainya. Selain dari bambu, bahan dasar anyaman juga dapat berupa rotan, pandan, rumput-rumputan, kulit kayu, dan lain-lain. Pada masyarakat Jawa Barat, anyaman yang dikembangkan adalah anyaman berbahan dasar bambu. Bambu merupakan satu di antara bahan anyaman yang sangat kental dengan makna, terlebih jika dikaitkan dengan suku Sunda. Masyarakat Sunda sudah relatif lama berhubungan akrab dengan bambu, banyak pengalaman leluhur yang bisa dipetik, sejak lahir hingga mati, orang Sunda selalu dipertemukan dengan bambu (Mahzuni, Zakaria \& Septiani, 2017).

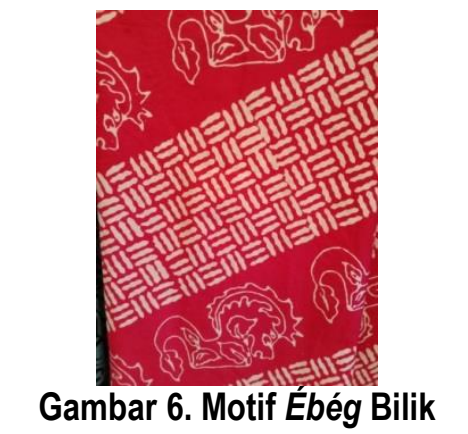

Sumber: Dokumentasi Pribadi, 2021.

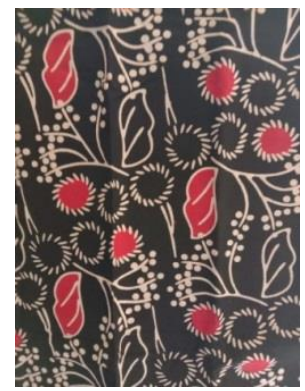

Gambar 7. Motif Si Batulawang

Sumber: Dokumentasi Pribadi, 2021.

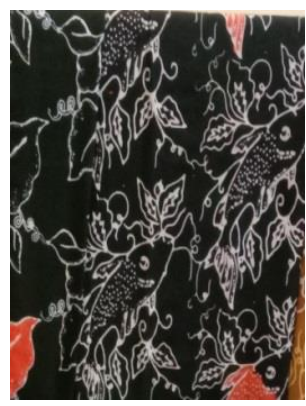

Gambar 9. Motif Parakan Kuwu Sumber: Dokumentasi Pribadi, 2021.

Inspirasi penciptaan motif Batik Si Batulawang ini adalah keberadaan Buah Rambutan khas di Kota Banjar tepatnya di daerah Batulawang. Menurut Heri pengangkatan Motif Batik Rambutan ini berdasarkan keberadaan Rambutan unggul yang berada di Kota Banjar daerah Batulawang yang bertujuan untuk promosi batik khas Kota Banjar selain itu juga untuk mengangkat pamor dari keberadaan rambutan Khas Kota Banjar (Heri wawancara 22 Mater 2021). Penggunaan warna Batik Motif Rambutan ini adalah warna dasar berwarna hitam dan warna pada coraknya putih dan merah. Warna hitam, melambangkan kekuatan, penuh percaya diri, perlindungan, elegan, megah, 
sementara warna merah melambangkan membangkitkan energi, aktif, agresif hangat, komunikatif, aktif, optimis, antusias, dan bersemangat. Sedangkan warna putih mempunyai makna kemurnian, kepolosan, memberi kesan perlindungan, ketentraman, kenyamanan (Yunita, 2016).

Motif Batik Parakan Kuwu merupakan perpaduan antara motif Tarum yang dipadukan dengan Motif Bébéong. Bébéong merupakan salah satu jenis ikan yang banyak dijumpai di sepanjang aliran Sungai Citanduy, nama Parakan Kuwu diambil dari salah satu daerah yang digunakan sebagai tempat pemancingan oleh masyarakat Kota Banjar, disana habitat ikan kebanyakan adalah Ikan Bebeong. Jadi salah satu upaya untuk melestarikan jenis ikan ini selain dibudidayakan adalah dengan menggambarkan pada batik (Yadi wawancara 29 Juni 2021). Hal ini memberikan arti bahwasanya Sungai Citanduy memanglah sangat berpengaruh dan memiliki banyak manfaat bagi kehidupan masyarakat Kota Banjar. Penggunaan warna Motif Batik Tarum Bébéong cenderung sama dengan Batik Motif Rambutan yang menggunakan warna dasar berwarna hitam serta warna putih dan merah pada coraknya.

Adapun nilai-nilai dari Batik Kota Banjar adalah sebagai berikut:

\section{a. Nilai Estetik (nilai keindahan)}

Menurut Martin Suryajaya secara etimologis, istilah estetika berasal dari kata sifat dalam Bahasa Yunani, aisthetikos yang artinya persepsi indrawi (Susanti, 2018). Hal ini dapat dijabarkan bahwa nilai estetik adalah apresiasi terhadap karya seni melalui indrawi yang dapat dirasakan oleh manusia. Nilai estetik yang tertuang pada Batik Khas Kota Banjar adalah keindahan yang dapat dilihat melalui indra penglihatan manusia dengan keberagaman corak dan warna yang menjadi kesatuan dalam sebuah karya seni. Karena keindahan yang terdapat pada seni batik, produksi kain batik juga dijadikan sebagai bahan pembuatan busana maupun kerajinan lainnya yang dapat dinikmati kegunaan dan keindahan dalam karya batik.

\section{b. Nilai Ekonomi}

Keberadaan industri batik di Kota Banjar memiliki sumbangsi tehadap perekonomian masyarakat. Seiring dengan perkembangan zaman kegunaan batik semakin beragam, batik dijadikan sebagai fashion masyarakat, baik dalam busana maupun kerajinan lainnya. Keindahan dan kegunaan yang terdapat pada batik menjadikan batik dapat dijadikan sebagai salah satu kegiatan ekonomi masyarakat. Batik menjadi salah satu pendongkrak ekonomi masyarakat, dengan adanya indusri-industri batik di Kota Banjar yang menciptakan lapangan pekerjaan baru bagi masyarakat Kota Banjar dan hasil karya dari batik ini mendapat apresiasi dari peminat batik dengan diperjual belikan kepada masyarakat umum.

\section{c. Nilai Sosial-Budaya}

Keberagaman budaya dan masyarakat Kota Banjar menjadikan sebuah inspirasi terciptanya motif batik di Kota Banjar. Kerukunan yang terjalin pada masyarakat Kota Banjar meskipun memiliki kebudayaan yang berbeda tetapi dapat hidup berdampingan. Tradisi membatik yang telah dikenal masyarakat Indonesia sejak dulu, dengan masih berkembangnya tradisi membatik dikalangan masyarakat modern merupakan salah satu wujud dari pelesratian budaya. Selain itu kegiatan membatik tidaklah bisa dikerjakan seorang diri, karena itu membatik juga mengajarkan pentingnya kerjasama dan interaksi antar pembatik satu dengan yang lainnya untuk melakukan tahap demi tahap dalam pembuatannya sehingga mendapatkan karya yang maksimal. Hal ini terlihat bahwa masyarakat Kota Banjar berupaya untuk saling bekerjasama dalam memajukan Kota Banjar.

\section{d. Nilai Pendidikan}

Pada era globalisasi ini nilai-nilai dari luar mudah mempengaruhi pemikiran dan karakter generasi (generasi masa kini) sehingga menimbulkan kekhawatiran terhadap pengikisan jatidiri yang terkait merosotnya penghayatan nilai-nilai keagamaan, nasionalisme, nilai sosial budaya bangsa dan perkembangan moralitas individu (Baharudin, 2020). Pendidikan yang terdapat dalam seni batik memberikan pembelajaran bahwa pentingnya menjaga dan melestarikan warisan budaya bangsa dan juga keluhuran nilai-nilai filosofisnya yang dapat diterapkan dalam kehidupan. Nilai-nlai filosofis yang terkandung daam batik pula dapat dijadikan sebagai pembelajaran kepada siswa di sekolah 
sebagai generasi penerus bangsa agar lebih menjaga dan mencintai warisan budayanya. Pengenalan seni batik secara tidak langsung mengajarkan nilai-nilai karakter yang dapat membentuk kepribadian baik pada siswa. Kesadaran sejarah dan budaya merupakan hal terpenting untuk menemukan kembali identitas bangsa. Dalam pembelajaran sekolah adalah sarana yang tepat membangkitkan kesadaran sejarah karena dalam pembelajaran yang diadakan di sekolah lebih terstruktur (Wijayanti. 2017). Batik dapat digunakan sebagai sarana edukasi, gambar yang dituangkan dalam batik selain mengandung unsur estetika juga mengandung makna yang baik untuk membentuk karakter siswa dan mengetahui darimana mereka berasal serta bagaimana kondisi lingkungan tempat tinggalnya. Hal ini dapat menjadikan siswa lebih mencintai tanah airnya dengan keberagaman yang menjadi pemersatu dengan melihat kondisi lingkungannya yang tertuang dalam motif-motif batik.

Berdasarkan uraian di atas nilai-nilai filosofis adalah esensi yang melekat pada sesuatu yang sangat berarti bagi kehidupan manusia, khususnya mengenai kebaikan dan tindak kebaikan suatu hal. Nilai kita rasakan dalam diri kita masing-masing sebagai daya pendorong atau prinsipprinsip yang menjadi penting dalam kehidupan. Keberadaan batik Kota Banjar ini sangatlah menggambarkan kondisi sosio-kultural Kota Banjar yang tertuang dalam setiap motif-motifnya.

\section{KESIMPULAN}

Batik khas daerah Kota Banjar merupakan hasil kerajinan yang tercipta dan memunculkan motif Tarum Ébég serta dinyatakan resmi menjadi batik khas kota Banjar. Setelah berkembangnya batik tersebut, dilakukannya inovasi-inovasi baru dengan menciptakan dan megkolaborasikan motif Tarum Ébég dengan motif-motif lain, seperti: Motif Réréng Ébég yang mengkolaborasikan motif Réréng atau motif Parang dengan motif Ébég, Motif Réréng Tarum yang mengkolaborasikan motif Réréng dengan motif Tarum, Motif Ébég. Bilik yaitu kolaborasi antara motif Ébég dan Motif Bilik yang merupakan kerajinan anyaman dari bambu, Motif Rambutan terinspirasi dari keberadaan rambutan lokal Kota Banjar yaitu Rambutan Sibatulawang di Daerah Batulawang, dan Motif Parakan Kuwu yang terinspirasi dari salah satu jenis ikan yang banyak dijumpai di Sungai Citanduy khususnya pada daerah pemancingan Parakan Kuwu dan menjadi habitat Ikan Bébéong. Untuk tetap mempertahankan eksistensi batik Khas Kota Banjar pemerintah menetapkannya sebagai salah satu pakaian dinas yang wajib dikenakan oleh jajaran Pemerintahan Kota Banjar.

Nilai-nilai filosofis Batik Khas Kota Banjar yaitu, 1) Nilai Estetik atau nilai keindahan (sederhana namun tetap terlihat elegan); 2) Nilai Sosial-Budaya (kerukunan dan keselarasan masyarakat meskipun memiliki keberagaman budaya namun dapat hidup berdampingan untuk memajukan Kota Banjar); 3) Nilai Ekonomi, batik menjadi salah satu pendongkrak ekonomi masyarakat, dengan adanya indusri-industri batik di Kota Banjar yang menciptakan lapangan pekerjaan baru bagi masyarakat Kota Banjar; dan 4) Nilai Pendidikan, memberikan pembelajaran bahwa pentingnya menjaga dan melestarikan warisan budaya bangsa dan jugaa keluhuran nilai-nilai filosofisnya.

\section{REKOMENDASI}

Batik Khas Kota Banjar merupakan salah satu aset yang harus dibanggakan oleh masyarakat Kota Banjar, oleh karena itu diharapkan penggunaannya di setiap acara, sehingga akan memiliki rasa bangga terhadap batik khas daerah Kota Banjar dan menjaga keaslian batik Khas Kota Banjar, meskipun telah disesusaikan dengan perkembangan zaman. Pemerintah daerah harus konsisten dalam mengawal peraturan daerah tentang penggunaan batik setiap hari Kamis, pembinaan lebih lanjut terhadap para industri batik agar kualitas batik khas Kota Banjar dapat bersaing di pasaran, mengadakan sekolah membatik agar adanya sebuah regenerasi dan mengurangi angka pengangguaran dan Disperindag memfasilitasi pemasaran batik Kota Banjar. 


\section{UCAPAN TERIMAKASIH}

Ucapan terimakasih ini penulis tujukan kepada pemda kota Banjar dan industri batik di kota Banjar serta pihak-pihak yang telah membantu dalam penelitian ini.

\section{DAFTAR PUSTAKA}

Musman, A., \& Arini, A. B. (2011). Batik: Warisan Adiluhung Nusantara. Yogyakarta: G-Media.

Baharudin. (2020). Nilai-Nilai Moral Masyarakat Sunda (Kajian Naskah Sewaka Darma Di Situs Kabuyutan Ciburuy Garut). J-KIP (Jurnal Keguruan dan IImu Pendidikan), 1 (2), 41-46.

Daliman, A. (2018). Metode Penelitian Sejarah. Yogyakarta: Ombak.

https://banjarkota.go.id/kondisi-geografis/. Diakses pada 08 maret 2021

https://www.tokopedia.com/liana-sidomulyo/kuda-lumping-asli-untuk-pentas. Diakses pada 29 April 2021.

https://peraturan.bpk.go.id. Diakses pada 07 Juni 2021

Herlina, N. (2020). Metode Sejarah. Bandung: Satya Historika.

Herdiana, Soedarmo, U. R., \& Kusmayadi, Y. (2020). Motif Ragam Hias dan Nilai-Nilai Filosofis Batik Ciamis. Jurnal Artefak, 7(1), 53-62.

Hidayatuloh, S. (2019). Nilai-Nilai Kearifan Lokal Upacara Adat Ngikis di Situs Karangkamulyan Kabupaten Ciamis. Patanjala, 11(1), 97-113.

Kusdiani, M. M. (2018). Analisis Motif Batik Tarum-Ëbēg sebagai Motif Batik Khas Kota Banjar Patroman, Jawa Barat. Pendidikan Kriya, 54-65.

Kusriyanto, A. (2013). Batik. Yogyakarta: C.V. ANDI OFFSET.

Lalak. (2021, Maret 1). Wiraswasta.

Mahzuni, D., Zakaria, M. M., \& Septiani, A. (2017). Pengembangan Kerajinan Tangan Berbasis Kearifan Budaya Di Pakenjeng Kabupaten Garut. Dharmakarya, 6(2), 101 - 105.

Mimin. (2021, Februari 2021). Pengrajin Batik.

Neni. (2021, Februari 18). Pengrajin Batik

Purnamasari, D. A. (2015). Sejarah Perkembangan Makna dan Nilai Filosofis Batik Sirkit Khas Kabupaten Kebumen Provinsi Jawa Tengah. Purworejo: Universitas Muhammadiyah Purworejo.

Supriono, P. (2016). Ensiklopedia The Heritage Of Batik. Yogyakarta: C.V. Andi Offset.

Susanti, G. I. (2018). Kajian Estetika Sekar Jagad Motif Mancungan Kebumen. Yogyakarta: Universitas Negeri Yogyakarta. 
Susanto, H. (2021, Maret 22). Teknisi Batik.

Tyas, F. Y. (2013). Analisis Semiotika Motif Batik Khas Samarinda. eJournal Ilmu Komunikasi, 1 (4), 328-339.

Wijayanti, Y. (2017). Peranan Penting Sejarah Lokal dalam Kurikulum di Sekolah Menengah Atas. Jurnal Artefak, 4(1), 53-60.

Yunita, Y. (2016). Makna Filosofis Batik Kendal. Semarang: Universitas Negeri Semarang. 
